\title{
SPATIAL AND TEMPORAL DISTRIBUTION OF PROTOZOA AT CUEVA DE LOS RISCOS, QUERÉTARO, MÉXICO
}

\author{
Itzel Sigala-Regalado', Rosaura Mayén-Estrada' ${ }^{1,2}$, And Juan B. Morales-Malacara 3,4
}

\begin{abstract}
Protozoa are important members of ecosystems, but protozoa that inhabit caves are poorly known worldwide. In this work, we present data on the record and distribution of thirteen protozoa species in four underground biotopes (water, soil, bat guano, and moss), at Cueva de Los Riscos. The samples were taken in six different months over more than a year. Protozoa species were ciliates (eight species), flagellates (three species), amoeboid (one species), and heliozoan (one species). Five of these species are reported for the first time inside cave systems anywhere, and an additional three species are new records for Mexican caves. Colpoda was the ciliate genera found in all cave zones sampled, and it inhabited the four biotopes together with Vorticella. The biotopes with the highest specific richness were the moss, sampled near the main cave entrance, and the temporary or permanent water bodies, with ten species each. The greatest number of species was observed in April 2006 (dry season). With the exception of water, all biotopes are studied for the first time.
\end{abstract}

\section{INTRODUCTION}

A great extent of Mexican territory is formed by sedimentary rocks that permit the formation of caves, but the number, location, and biodiversity of Mexican caves is only partially known. Records of subterranean protozoan taxa in Mexico are scarce, and refer only to caves in San Luis Potosí and Guerrero states (Osorio-Tafall, 1943; Hoffmann et al., 1986, p. 206-207), in which thirty species of sarcodines and ciliates have been reported.

There are records of nine protozoa species from caves in North America. In Bermuda, Hill et al. (1986) recorded Euplotes iliffei in subterranean anchialine habitats and Small et al. (1986) recorded Glauconema bermudense in marine caves. Holsinger (1966) found Paramecium multimicronucleatum and Spirostomum ambiguum in Virginia, and Barr (1968) reported Phacus sp., Paramecium sp., Halteria sp., Difflugia sp., and Peranema sp. as free-living inhabitants of the Mammoth Cave system in Kentucky.

Protozoa are cosmopolitan and tolerate a wide range of physicochemical factors, including $\mathrm{pH}$, temperature, oxygen concentration, and salinity. They are not randomly distributed, but live in microhabitats, small regions that may be as tiny as a few cubic centimeters, within a body of water or a moist environment such as soil, vegetation, or the bodies of plants and animals (Bamforth, 1985). They occupy many different biotopes, in the sense of Olenin and Ducrotoy (2006).

According to Hoffmann et al. (1986, chap. III), roots, leaf and animal debris, and the guano of bats provide the primary energy sources in open system caves. Indeed, guano is considered the most important biotope, but water, soil, and moss also play important roles as sustainable habitats for diverse communities of microorganisms and metazoan taxa.
The protozoan trophozoite or cyst phase enters caves in water flow or infiltration through soil, in air currents, and by troglophile fauna present in the cave (Golemansky and Bonnet, 1994) and accidental or trogloxene organisms. The aim of this work is to record and analyze protozoan spatial and temporal distribution associated with different biotopes over more than a year at Cueva de Los Riscos.

\section{Materials AND Methods}

Cueva de Los Riscos is located in Jalpan de Serra, Querétaro, Mexico, at $1122 \mathrm{~m}$ asl, $21^{\circ} 11^{\prime} 38^{\prime \prime} \mathrm{N}$, $99^{\circ} 30^{\prime} 50^{\prime \prime} \mathrm{W}$. It is a mixed underground system (horizontal and vertical) with a length of $440 \mathrm{~m}$ (Lazcano-Sahagún, 1986a, p. 32; 1986b, p. 77-79), with four zones (A-D) and four entrances (Fig. 1); a detailed cave description is in Espino del Castillo et al. (2009).

Six visits were made to Cueva de Los Riscos from November 2005 to June 2007 (Table 1). Samples, including water, soil, bat guano, and moss, were collected where available in four large zones in the cave, A, B, C, and D (Fig. 1); other areas in narrow tunnels were not sampled. Access to the cave was done without special equipment, but for biosafety we wore face masks with filters (Milter disposable 3M 8210 N95).

Water samples were collected by using sterile pipettes; guano and soil samples were obtained with sterilized metallic

\footnotetext{
${ }^{1}$ Protozoología, Departamento de Biología Comparada, Facultad de Ciencias, Universidad Nacional Autónoma de México, Coyoacán 04510, D.F., México

${ }^{2}$ Corresponding Author. Ap. Postal 70-374, C.P. 04510, Ciudad Universitaria, México, D.F. México.romaraf@gmail.com

${ }^{3}$ Acarología \& Bioespeleología, Departamento de Biología Comparada, Facultad de Ciencias, Universidad Nacional Autónoma de México, Coyoacán 04510, D.F., México

${ }^{4}$ Additional Address: Unidad Multidisciplinaria de Docencia e Investigación, Facultad de Ciencias, Universidad Nacional Autónoma de México, Campus Juriquilla, Boulevard Juriquilla 3001, C.P. 76230, Querétaro, Querétaro, México
} 

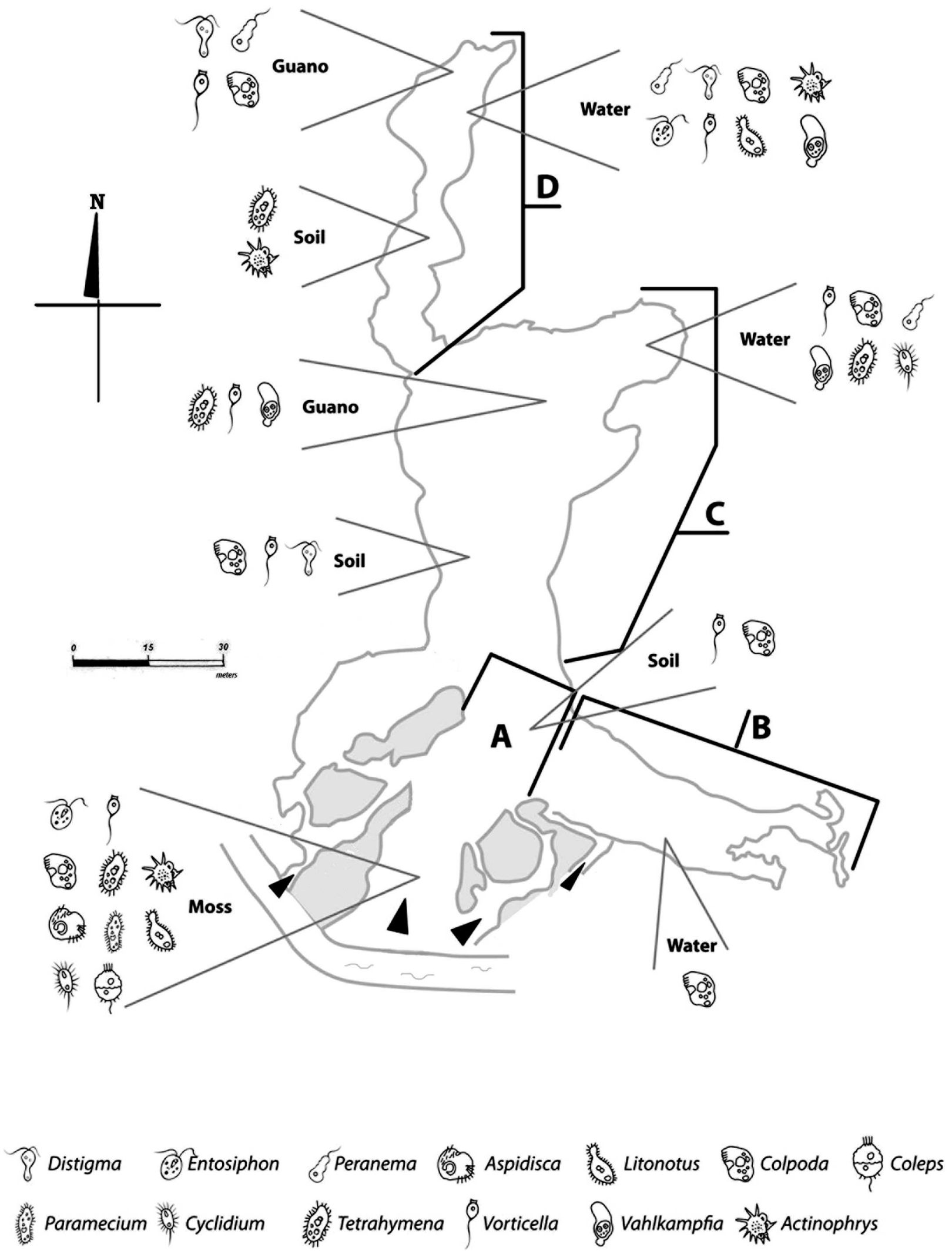

Figure 1. Cueva de Los Riscos map drawn by D. McKenzie of the Association for Mexican Cave Studies in 1966 (Lazcano Sahagún, 1986b, p. 79), modified by A. Espino del Castillo, M. Hernández, J.B. Morales-Malacara, and L. González of the Universidad Nacional Autónoma de México in March 2007, showing collecting places and species biodiversity at each biotope. Black arrow heads represent cave entrances. 


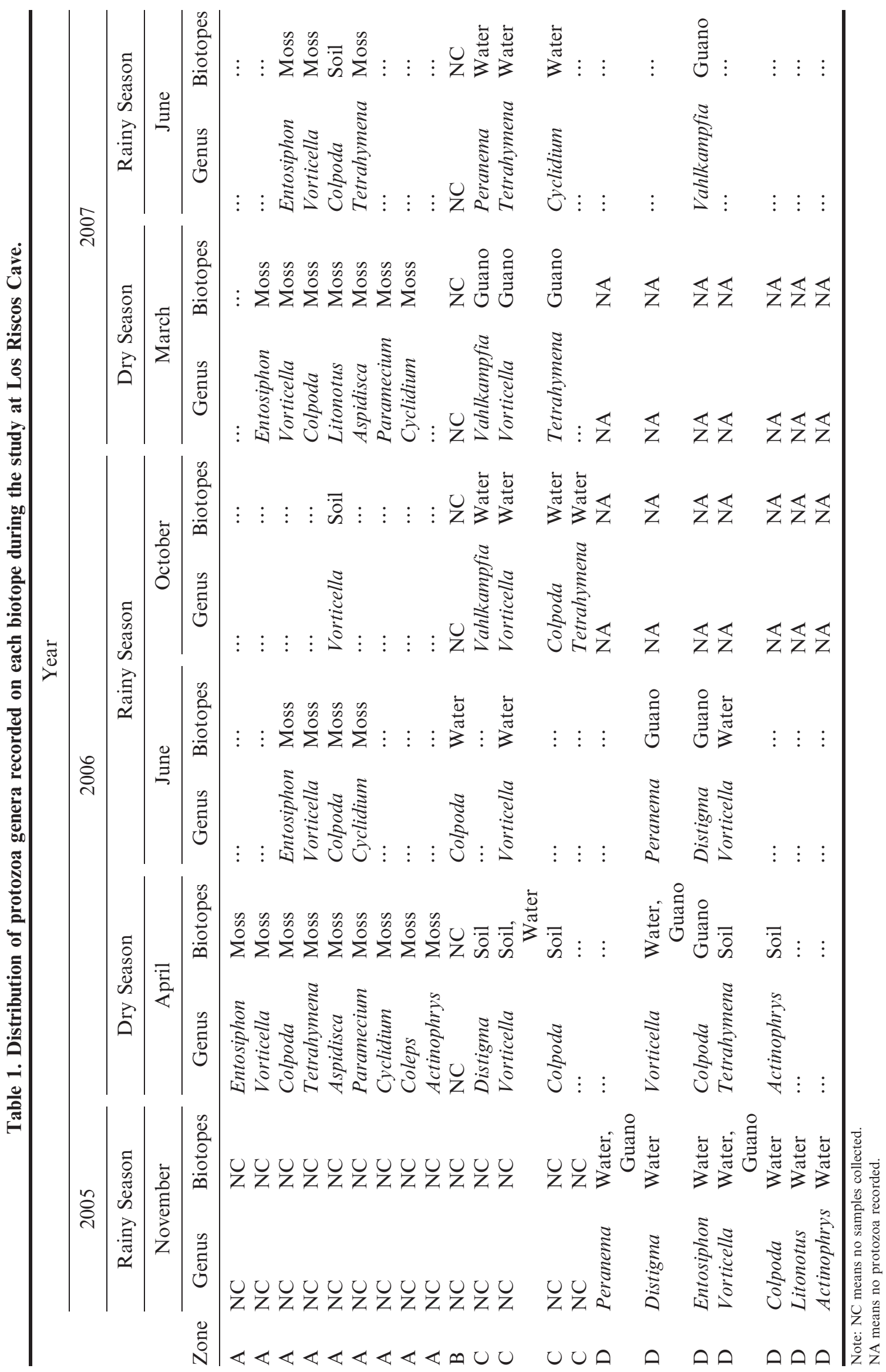



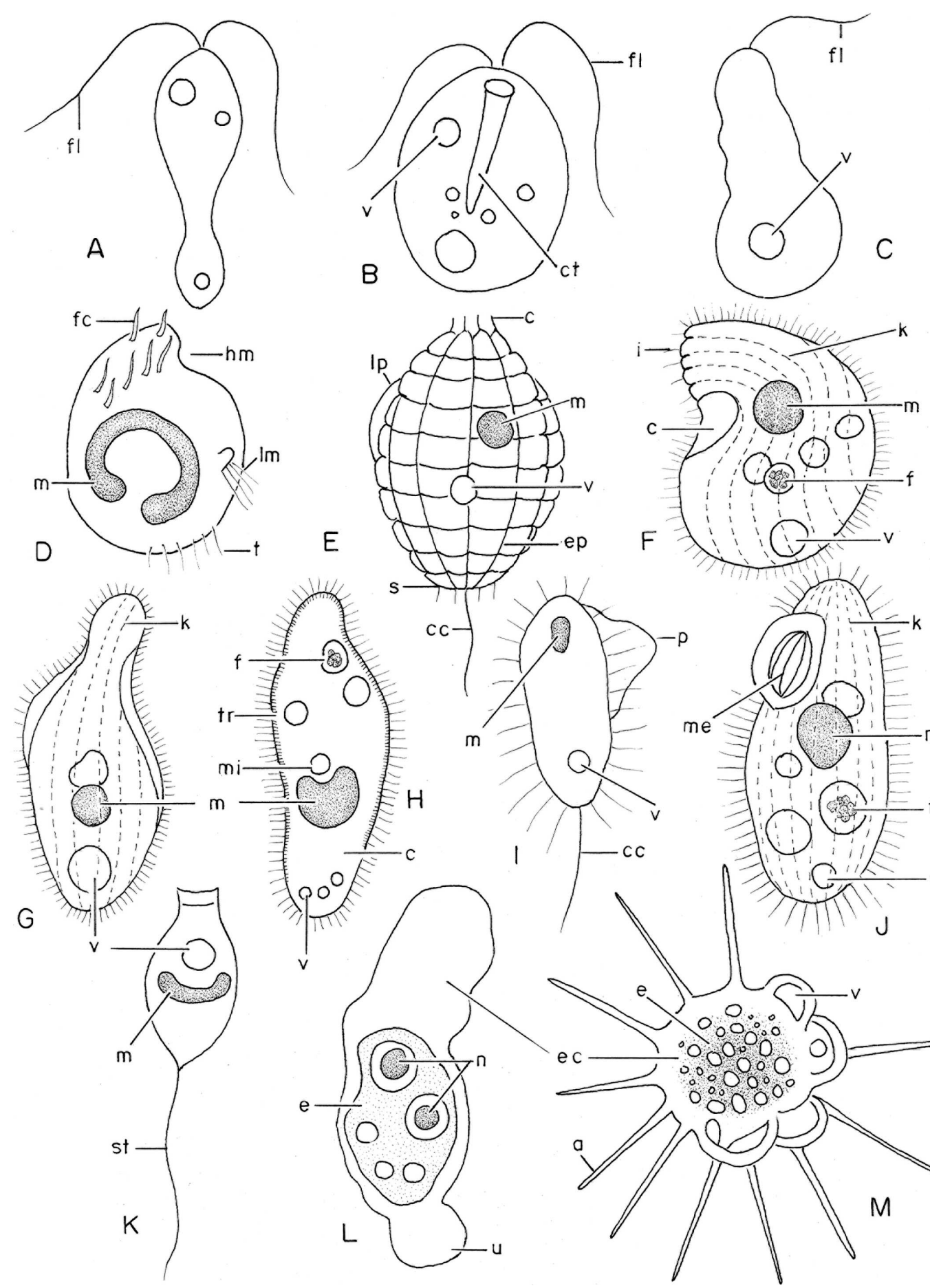

$\mathrm{CC}$
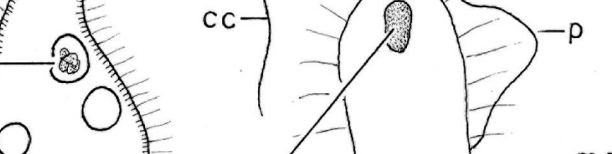
spoons, and for moss we utilized forceps. Approximately $2 \mathrm{ml}$ or 2 cc of each sample was placed in one sterilized Falcon tube containing $5 \mathrm{ml}$ of nutritive sterile pea infusion (Patterson and Hedley, 1992, p.17-18). Additionally, $100 \mathrm{ml}$ or $100 \mathrm{cc}$ of each sample was collected in sterilized $100 \mathrm{ml}$ glass jars. Moss samples were collected in plastic bags. All samples were transported in a cooler without ice, in order to maintain all samples in good condition.

All laboratory procedures started within 24 hours of collection. In all cases, to obtain polyxenic cultures (multiple species), $2 \mathrm{ml}$ of each sample was added to natural infusions of straw, rice, wheat, pea, and corn (Lee et al. 1985; Jahn et al. 1979, p. 10-12) and chemical media (Chalkley, peptone, and RPMI-1640 Sigma) (Manwell, 1968, p. 559-572; Kudo, 1971, p. 848-852). The samples and cultures were maintained in the dark at $25{ }^{\circ} \mathrm{C}$ in an incubator, except for the moss samples, which were exposed to sunlight. To identify the protozoa and for a photomicrographic record, all the cultures were periodically examined by using phase-contrast, differential-interference-contrast and bright-field microscopes (Nikon Labophot-2 with Nikon Digital Sight DS-2Mv and Nikon FX-35DX incorporated camera; Zeiss Axioskop 2 plus with Zeiss AxioCam MRC system). Diagnostic characters were studied with staining and impregnation techniques such as Harris hematoxylin, Klein, protargol, and butanolnigrosine (Borror, 1969; Kudo, 1971, p. 863; Lee et al., 1985; Silva-Neto, 2000).

We utilized the Jaccard index to estimate the degree of similarity between biotopes with regard to genera. The similarity values obtained were summarized by clustering, using the UPGMA method (program NTSYS pc. v. 2.2, Exeter Software, Setauket, New York).

\section{RESUltS}

We identified thirteen protozoa species, with three flagellates (Entosiphon sp., Distigma sp., Peranema sp.), one naked amoebae (Vahlkampfia sp.), one heliozoan (Actinophrys sol Ehrenberg), and eight ciliates [Aspidisca sp., Litonotus sp., Colpoda sp., Coleps hirtus (O. F. Müller), Paramecium caudatum Ehrenberg, Cyclidium sp., Tetrahymena pyriformis (Ehrenberg), and Vorticella sp.] (Table 1, Fig. 2). The protozoan distribution in relation to the cave zones and biotopes from all seasons is shown in Figure 1.

The species Entosiphon sp., Distigma sp., Aspidisca sp., Litonotus sp., and Tetrahymena pyriformis have not been recorded in caves anywhere in the world. The following species are new records for Mexican caves: Actinophrys sol, Colpoda sp., and Paramecium caudatum (Table 2).

The relative species richness among the cave biotopes, seasons, and zones, is shown in Figures 1 and 3. The most diverse biotopes were moss and water, and the soil was the least diverse (Table 1).

The greatest number of protozoan taxa was present in April 2006 (dry season), and the lowest was in October

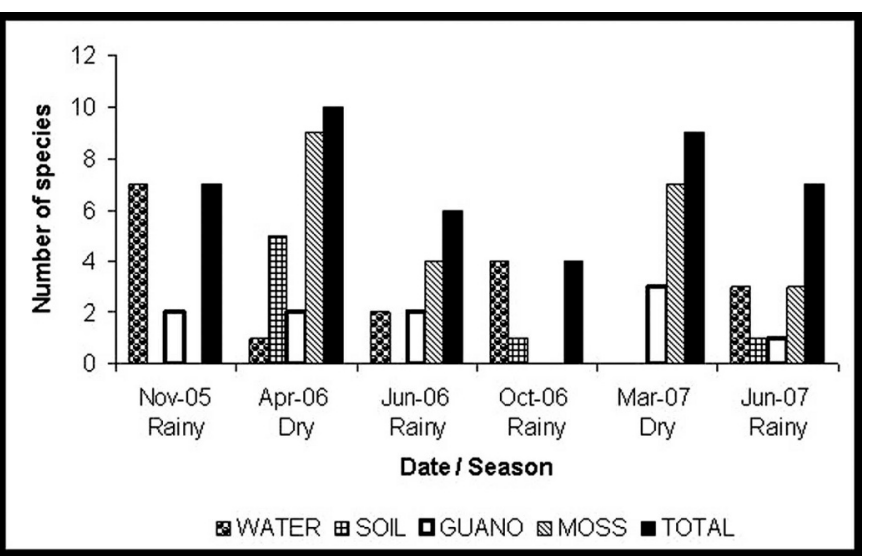

Figure 3. Number of protozoa species for each biotope and season at Cueva de Los Riscos. Note that some species appear in the totals for more than one biotope for each date.

(rainy season) of the same year, when flagellates were absent, with Zone A having the highest diversity

The genus Colpoda was found on all biotopes, zones, and periods. Vorticella sp. and Tetrahymena pyriformis were recorded in all biotopes and during all periods. The genus Coleps was recorded only in Zone A moss in April 2006.

Entosiphon was recorded in samples from five months (rainy and dry seasons), except for October 2006. The heliozoan Actinophrys sol was observed only in November 2005 (rainy season) and April 2006 (dry season). The amoeboid genus Vahlkampfia was recorded three times: October 2006 (rainy season), March 2007 (dry season), and June 2007 (rainy season).

In Zone B, we found only the genus Colpoda, which was observed in a draining water sample.

From the Jaccard similarity index two clusters were obtained; the first grouped the biotopes water, guano, and soil, and the second cluster included only the moss biotope. We obtained a similarity index of 0.6 between the water and guano biotopes, a similarity of 0.54 when both biotopes were compared with the soil, and a similarity of 0.38 when these three biotopes were compared with the moss.

\section{DisCUSSION}

According to Corliss (2002), the protists are cosmopolitan in overall distribution, and, in particular, most protozoa play roles mainly as phagotrophs (particulate consumers). Free-living species have a very broad distribution as planktonic or benthic forms. Free-swimming flagellates and ciliates are the most important consumers of bacteria in aquatic and terrestrial ecosystems.

Considering the functional groups of protozoa in ecosystems proposed by Pratt and Cairns (1985), the species found in the biotopes at Cueva de Los Riscos 
Table 2. Genera recorded in this study, with previous cave records, if any.

\begin{tabular}{|c|c|c|c|c|c|}
\hline \multicolumn{4}{|c|}{ Previous Records } & \multirow{2}{*}{$\begin{array}{l}\text { Los Riscos } \\
\text { Cave }^{\mathrm{a}}\end{array}$} & \multirow[b]{2}{*}{ Record } \\
\hline Europe & USA & México & References & & \\
\hline$\cdots$ & Peranema sp. & $\cdots$ & Barr, 1986 & Peranema sp. & $\mathrm{P}$ \\
\hline$\cdots$ & $\cdots$ & Peranema sp. & $\begin{array}{l}\text { Hoffmann et al., } \\
1986\end{array}$ & & \\
\hline$\cdots$ & $\cdots$ & Vahlkampfia sp. & $\begin{array}{l}\text { Hoffmann et al., } \\
1986\end{array}$ & Vahlkampfia sp. & $\mathrm{P}$ \\
\hline$V . \operatorname{limax}$ & $\cdots$ & $\cdots$ & $\begin{array}{c}\text { Golemansky and } \\
\text { Bonnet, } 1994\end{array}$ & & \\
\hline V. magna & $\cdots$ & $\cdots$ & $\begin{array}{c}\text { Golemansky and } \\
\text { Bonnet, } 1994\end{array}$ & & \\
\hline V. tachipodia & $\cdots$ & $\cdots$ & $\begin{array}{l}\text { Golemansky and } \\
\text { Bonnet, } 1994\end{array}$ & & \\
\hline $\begin{array}{l}\text { Cyclidium } \\
\text { oligotrichum }\end{array}$ & $\cdots$ & $\cdots$ & Carey et al., 2001 & Cyclidium sp. & $\mathrm{P}$ \\
\hline C. fuscum & $\cdots$ & $\cdots$ & Carey et al., 2001 & & \\
\hline C. glaucoma & $\cdots$ & $\cdots$ & $\begin{array}{l}\text { Golemansky and } \\
\text { Bonnet, } 1994\end{array}$ & & \\
\hline$\cdots$ & $\cdots$ & Cyclidium sp. & $\begin{array}{l}\text { Hoffmann et al., } \\
1986\end{array}$ & & \\
\hline$\cdots$ & $\cdots$ & $\cdots$ & & & \\
\hline$\cdots$ & $\cdots$ & Tetrahymena sp. & $\begin{array}{l}\text { Hoffmann et al., } \\
1986\end{array}$ & $\begin{array}{l}\text { Tetrahymena } \\
\text { pyriformis }\end{array}$ & $\mathrm{P}$ \\
\hline$\cdots$ & $\cdots$ & Vorticella sp. & $\begin{array}{l}\text { Hoffmann et al., } \\
1986\end{array}$ & Vorticella sp. & $\mathrm{P}$ \\
\hline$\cdots$ & $\cdots$ & $\begin{array}{l}\text { Vorticella sp. cf. } \\
\text { microstoma }\end{array}$ & Osorio-Tafall, 1943 & & \\
\hline Colpoda sp. & $\cdots$ & $\cdots$ & Barr, 1986 & Colpoda sp. & M \\
\hline C. steinii & $\cdots$ & $\ldots$ & $\begin{array}{c}\text { Golemansky and } \\
\text { Bonnet, } 1994\end{array}$ & & \\
\hline $\begin{array}{l}\text { Paramecium } \\
\text { caudatum }\end{array}$ & $\cdots$ & $\cdots$ & $\begin{array}{c}\text { Golemansky and } \\
\text { Bonnet, } 1994\end{array}$ & $\begin{array}{l}\text { Paramecium } \\
\text { caudatum }\end{array}$ & M \\
\hline$\cdots$ & Paramecium sp. & $\cdots$ & Barr, 1986 & & \\
\hline$\cdots$ & P. micromultinucleatum & $\cdots$ & Holsinger, 1966 & & \\
\hline$\cdots$ & $\cdots$ & P. aurelia & $\begin{array}{l}\text { Hoffmann et al., } \\
1986\end{array}$ & & \\
\hline Actinophrys sol & $\cdots$ & $\cdots$ & $\begin{array}{c}\text { Golemansky and } \\
\text { Bonnet, } 1994\end{array}$ & Actinophrys sol & M \\
\hline A. vesiculata & $\cdots$ & $\cdots$ & $\begin{array}{l}\text { Golemansky and } \\
\text { Bonnet, } 1994\end{array}$ & & \\
\hline ... & $\cdots$ & Actinophrys sp. & Osorio-Tafall, 1943 & & \\
\hline$\cdots$ & $\cdots$ & Coleps sp. & $\begin{array}{l}\text { Hoffmann et al., } \\
1986\end{array}$ & Coleps hirtus & W \\
\hline$\cdots$ & $\cdots$ & $\begin{array}{l}\text { Coleps sp. cf. } \\
\text { hirtus }\end{array}$ & Osorio-Tafall, 1943 & & \\
\hline ... & $\ldots$ & $\ldots$ & $\ldots$ & Entosiphon sp. & W \\
\hline ... & $\ldots$ & ... & $\ldots$ & Distigma sp. & $\mathrm{W}$ \\
\hline$\cdots$ & $\cdots$ & $\cdots$ & $\cdots$ & Aspidisca sp. & W \\
\hline$\cdots$ & $\cdots$ & $\cdots$ & $\cdots$ & Litonotus sp. & W \\
\hline
\end{tabular}

a This study.

W-New world and Mexican record for caves.

M-New Mexican record for caves.

$\mathrm{P}-$ Previously recorded in Mexican caves. 
correspond to bactivores-detritivores (Aspidisca sp., Colpoda sp., Coleps hirtus, Cyclidium sp., Litonotus sp., Paramecium caudatum, Tetrahymena pyriformis, Vorticella sp., Entosiphon sp. and Peranema sp.), saprotophs (Distigma sp.), and non-selective omnivores (Actinophrys sol). Foissner and Berger (1996) reported some species of Litonotus as predators. The main functional role of substrate-associated protozoa is the processing of dead organic matter and its associated bacterial flora (Pratt and Cairns, 1985).

Members of genera Coleps, Vorticella, Tetrahymena and Paramecium are very common in many ecosystems and have been previously reported in some cave biotopes (Table 2). Previous records of Mexican cave protozoa include species that were observed only in water samples, in contrast to our findings from multiple biotopes. As shown in Figure 1, Vorticella sp., a detritivorous genus, was recorded in all biotopes of the cave; therefore we consider this species as having a broad distribution.

The flagellates are typically smaller, but much more abundant than ciliates and often mixotrophic in their nutrition; they occupy both planktonic and benthic levels (Corliss, 2002). We found the genera Entosiphon, Distigma, and Peranema as benthic organisms.

The samples collected during October 2006 (rainy season) had the lowest diversity, with only four genera, probably because of the excessive water flow in the cave, as compared with April and May, that probably washed out protozoan populations. However, some puddles remained as propitious microhabitats for the development of protozoan communities and other organisms like small metazoans.

For the water biotope, we observed the highest species richness during November 2005 and October 2006 (rainy season). For the soil biotope we found the highest number of species during the spring months; however samples were not obtained for all collections during this period. The bat guano biotope presented only slight differences in species richness among seasons (Figure 3). April 2006 and March 2007 (dry season) had the highest number of species inhabiting the moss substrate.

We conclude for this cave system that the spring months, corresponding to the dry season, have the highest protozoan diversity.

According to Finlay et al. (1998), the same ciliate species are found wherever their preferred habitat is found. Free-living ciliates may be ubiquitous, as they are continually being distributed by effective passive dispersal; these statements can be taken into account when we analyze the protozoa recorded previously in world caves.

According to Hausman and Hülsmann (1996), some species of Colpoda can resist lower temperatures, which favors its establishment in several habitats. However, caves are systems where microclimate conditions are almost constant through the year in dark zones, and this environmental stability could be a dominant factor for some protozoa species found throughout the cave, such as Colpoda sp. and Vorticella sp.

Cyst production by protozoa is sometimes just part of the life-cycle, but often is a response to unfavorable environmental factors, such as desiccation, temperature, or starvation, and is triggered in response to these conditions. Cyst formation has been documented in species of the genera Colpoda, Vahlkampfia, Actinophrys, and Paramecium (Hausmann and Hülsmann, 1996, p. 154-157), which were found at Cueva de Los Riscos, and this capability facilitates the presence of these species in different seasons inside the cave.

The differences in specific richness in the cave zones can be explained as a function of the type of biotopes present. The greatest values were obtained in Zone A (the light zone), followed by Zone D (the darkest and deepest zone), and Zone $\mathrm{C}$ (the twilight and dark zone). The elevated specific richness of Zone A could be explained because of the presence of moss, a biotope that favors protozoan population growth. In Zone C, we found small bodies of water formed by temporary water sources, and also permanent gour pools, which provide a more suitable habitat for protozoan communities. Water facilitates oxygen uptake, contains food resources, has surface tension for movement and dispersion, and is a medium that also facilitates reproduction; this explains the record of seven protozoa genera. In Zone D, permanently dark and where vampire bats (Desmodus rotundus (Geoffroy) and Diphylla ecaudata Spix) were present in all seasons, the predominant biotope was the guano of the hematophagus bat, which had fewer species than the moss and water substrates, but provides nutrients such as nitrogen compounds for protozoa and is, according to Hoffmann et al. (1986, chap. III), a major energy source in caves, supporting five genera of heterotrophic protozoa. Zone B (twilight zone), had the lowest specific richness, but this can be due the small number of samples collected there because of its inaccessibility.

The Jaccard index demonstrated a similarity degree of 0.6 between the water and the bat guano biotopes, which shared mainly bactivore-detritivore species. Water and guano biotopes shared four species with the soil biotope, for a 0.54 similarity index. The biotopes guano, water, and soil were distributed into the darkest areas of the cave and proved to be suitable substrates for the protozoan colonization and establishment.

Soil is a microhabitat that could be frequently exposed to variable degrees of desiccation affecting the ciliates, flagellates and amoebaes. That could explain why we only found six species (three ciliates, one flagellate, and the heliozoan), as compared with other biotopes. However, a cave system usually exhibits high humidity, preventing desiccation. Nevertheless, protozoan diversity in soil was lowest, probably due to other factors, such as granulometric and physical characteristics that could prevent free movement and dispersion, among other functions. 
The community assemblages of several taxa of protozoans in the same time and place could be explained by their trophic roles in relation to the type and availability of food resources. The protozoa have a wide spectrum of food requirements, and these were available in the different cave biotopes documented. Broad tolerances of the most common taxa suggest that some species should be found in nearly every natural system (Pratt and Cairns, 1985) and explain why most of the species recorded in the present work also have been reported in habitats other than caves worldwide. In respect to this particular cave ecosystem, previous data refer only to protozoa from water samples of caves. We found that the all the biotopes considered in this study were suitable for many protozoa, favoring reproduction and providing food sources, among others requirements.

\section{Conclusions}

We sampled four biotopes in Cueva de Los Riscos that were inhabited by thirteen protozoa species. Each biotope provided favorable conditions, but they harbored different species compositions and richness throughout the dry and rainy seasons. We recorded for the first time five protozoa species in caves worldwide; an additional three species are new records for Mexican caves. With these data we conclude that protozoa have a wide distribution in cave systems, but more studies are needed to complete the records in these ecosystems.

\section{ACKNOWLEDGMENTS}

We are very grateful to $\mathrm{M}$. of Art Aldi de Oyarzábal (Facultad de Ciencias, Universidad Nacional Autónoma de México) for drawing Figures 1 and 2, and to Israel Díaz for Figure 1 digital processing. For comments on an earlier draft of the manuscript, we express our appreciation to Fernando Álvarez Padilla (Laboratorio de Acarología \& Bioespeleología, Facultad de Ciencias, Universidad Nacional Autónoma de México). We express our deepest gratitude to an anonymous reviewer for help in improving the manuscript. Financial assistance was provided by Dirección General de Asuntos del Personal Académico, Universidad Nacional Autónoma de México, Grant IN221906 to J.B.M-M.

\section{REFERENCES}

Bamforth, S.S., 1985, Ecology of protozoa, in Lee, J.J., Bovee, E.C., and Hutner, S.H., eds., An Illustrated Guide to the Protozoa: Lawrence, Kansas, Society of Protozoologists, p. 8-15.

Barr, T.C., 1968, Ecological studies in the Mammoth Cave System of Kentucky. I. The Biota. International Journal of Speleology, v. 3, no. $1-2$, p. 147-204.

Borror, A.C., 1969, Application of the stain-fixative Nigrosin- $\mathrm{HgCl}_{2-}$ Formalin to fragile or contractile ciliates: Transactions of the American Microscopical Society, v. 88, no. 3, p. 454 458.
Carey, P.G., Sargent, A.J., Martínez Taberner, A., Ramón, G., and Moyà, G., 2001, Ecology of cavernicolous ciliates from the anchialine lagoons of Mallorca. Hydrobiologia, v. 448, p. 193-201.

Corliss, J.O., 2002, Biodiversity and biocomplexity of the protists and an overview of their significant roles in maintenance of our biosphere: Acta Protozoologica, v. 41, p. 199-219.

Espino del Castillo, A., Castaño-Meneses, G., Dávila-Montes, M.J., Miranda-Anaya, M., Morales-Malacara, J.B., and Paredes-León, R., 2009, Seasonal distribution and circadian activity in the troglophile long-footed robber frog, Eleutherodactylus longipes (Anura: Brachycephalidae) at Los Riscos Cave, Querétaro, Mexico: Field and laboratory studies: Journal of Cave and Karst Studies, v. 71, no. 1, p. 24-31.

Finlay, B.J., Esteban, G.F., and Fenchel, T., 1998, Protozoan Diversity: Converging estimates of the global number of free-living ciliate species: Protist, v. 149 , p. 29-37.

Foissner, W., and Berger, H., 1996, A user-friendly guide to the ciliates (Protozoa, Ciliophora) commonly used by hydrobiologists as bioindicators in rivers, lakes, and waste waters, with notes on their ecology: Freshwater Biology, v. 35, p. 375-482.

Golemansky, V., and Bonnet, L., 1994, Protozoa, In: Juberthie, C., and V. Decu, V., eds., Encyclopaedia Bioespeologica: Société de Biospéologie, p. 23-33.

Hausmann, K., and Hülsmann, N., 1996, Protozoology: Stuttgart, Georg Thieme Verlag, $338 \mathrm{p}$.

Hill, B.F., Small, E.B., and Iliffe, T.M., 1986, Euplotes iliffei n. sp.; a new species of Euplotes (Ciliophora, Hypotrichida) from the marine caves of Bermuda. Journal of the Washington Academy of Sciences, v. 76, no. 4, p. 244-249.

Hoffmann, A., Palacios-Vargas, J.G., and Morales-Malacara, J.B., 1986, Manual de Bioespeleología (con nuevas aportaciones de Morelos y Guerrero, Méx.): Universidad Nacional Autónoma de México, $274 \mathrm{p}$.

Holsinger, J.R., 1966, A preliminary study on the effects of organic pollution of Banners Corner Cave, Virginia. International Journal of Speleology, v. 2, no. 1-2, p. 75-89.

Jahn, T.L., Bovee, E.C., and Jahn, F.F., 1979, How to Know the Protozoa: Dubuque, Iowa, Wm. C. Brown, 279 p.

Kudo, R.R., 1971, Protozoology: Springfield, Illinois, Charles C. Thomas, $1174 \mathrm{p}$.

Lazcano-Sahagún, C., 1986a, Cavernas de la Sierra Gorda. v. I: Universidad Nacional Autónoma de Querétaro, Mexico, 181 p.

Lazcano-Sahagún, C., 1986b, Cavernas de la Sierra Gorda. v. II: Universidad Nacional Autónoma de Querétaro, Mexico, 206 p.

Lee, J.J., Small, E.B., Lynn, D.H., and Bovee, E.C., 1985, Some techniques for collecting, cultivating and observing Protozoa, in Lee, J.J., Bovee, E.C., and Hutner, S.H., eds., An Illustrated Guide to the Protozoa: Lawrence, Kansas, Society of Protozoologists, p. 1-7.

Manwell, R.D., 1968. Introduction to Protozoology, second edition. New York, Dover, $642 \mathrm{p}$.

Olenin, S., and Ducrotoy, J.P., 2006, The concept of biotope in marine ecology and coastal management. Marine Pollution Bulletin, v. 53, p. $20-29$

Osorio-Tafall, B.F., 1943, Observaciones sobre la fauna acuática de las cuevas de la región de Valles, San Luis Potosí (México): Revista de la Sociedad Mexicana de Historia Natural, v. 4, no. 1-2, p. 43-71.

Patterson, D.J., and Hedley, S., 1992, Free-Living Freshwater Protozoa: A Colour Guide: London, Wolfe Publishing, 223 p.

Pratt, J.R., and Cairns, J., 1985, Functional groups in the Protozoa: roles in differing ecosysrems: Journal of Protozoology, v. 32, no. 3, p. 415-423, doi: 10.1111/j.1550-7408.1985.tb04037.x.

Silva-Neto, I.D., 2000, Improvement of silver impregnation technique (Protargol) to obtain morphological features of protists ciliates, flagellates and opalinates: Revista Brasileira de Biologia, v. 60, no. 3, p. 451-459, doi: 10.1590/S0034-71082000000300010.

Small, E.B., Heisler, J., Sniezek, J., and Iliffe, T.M., 1986, Glauconema bermudense n. sp. (Scuticociliatida, Oligohymenophorea), a troglobitic ciliophoran from Bermudian marine caves. Stygologia, v. 2, no. 1-2, p. $167-179$. 